\title{
Synthesis of $\mathrm{Li}_{1.6}[\mathrm{MnM}]_{1.6} \mathrm{O}_{4}(\mathrm{M}=\mathrm{Cu}, \mathrm{Ni}, \mathrm{Co}, \mathrm{Fe})$ and Their Physicochemical Properties as a New Precursor for Lithium Adsorbent
}

\author{
Yang-Soo Kim ${ }^{1}$, Won-Jin Moon ${ }^{1}$, Soon-Ki Jeong ${ }^{2}$, Dae-Hee Won ${ }^{3}$, Sang-Ro Lee ${ }^{4}$, \\ Byoung-Gyu Kim ${ }^{5}$ and Kang-Sup Chung ${ }^{5^{*}}$ \\ ${ }^{1}$ Korea Basic Science Institute \\ ${ }^{2}$ Dept. of Chemical Engineering,Soonchunhyang University \\ ${ }^{3}$ Hub Univ. for industrial collaboration, Sooncheon University, \\ ${ }^{4}$ KFNET. Co. LTD. \\ ${ }^{5}$ Korea Institute of Geoscience and Mineral Resources
}

\section{$\mathrm{Li}_{1.6}[\mathrm{MnM}]_{1.6} \mathrm{O}_{4}(\mathrm{M}=\mathrm{Cu}, \mathrm{Ni}, \mathrm{Co}, \mathrm{Fe})$ 의 합성 및 리틈 흡착제용 신규 전구체로서의 물리화학적 성질 \\ 김양수 ${ }^{1}$, 문원진 $^{1}$, 정순기 $^{2}$, 원대희 $^{3}$, 이상로 ${ }^{4}$, 김병규 $^{5}$, 정강섭 $^{5^{*}}$ \\ ${ }^{1}$ 한국기초과학지원연구원, ${ }^{2}$ 순천향대학교 공업화학과 \\ ${ }^{3}$ 순천대학교 산학협력중심대학, ${ }^{4}($ 주 $)$ KFNET, ${ }^{5}$ 한국지질자원연구원}

\begin{abstract}
New precursors as a $\mathrm{Li}$ adsorbent, $\mathrm{Li}_{1.6}(\mathrm{MnM})_{1.6} \mathrm{O}_{4}(\mathrm{M}=\mathrm{Cu}, \mathrm{Ni}, \mathrm{Co}, \mathrm{Fe})$, were synthesized by hydrothermal method and their physicochemical properties were discussed. XRD and HRTEM results revealed that the original spinel structure was stabilized by cobalt-doping while $\mathrm{Cu}$-, Ni- and $\mathrm{Fe}$-doping led to structural changes. Such a structural stabilization by Cobalt-doping was maintained after lithium leaching by acid treatment. Li absorption efficiency from seawater was significantly enhanced by using the Cobalt-doped spinel manganese oxide, $\mathrm{Li}_{1.6}[\mathrm{MnCo}]_{1.6} \mathrm{O}_{4}$, compared to the commercially available $\mathrm{Li}_{1.33} \mathrm{Mn}_{1.67} \mathrm{O}_{4}$; the adsorbed amount of $\mathrm{Li}$ from $1 \mathrm{~g}$-adsorbent was 35 and $16 \mathrm{mg}$ by $\mathrm{Li}_{1.6}[\mathrm{MnCo}]_{1.6} \mathrm{O}_{4}$, and $\mathrm{Li}_{1.33} \mathrm{Mn}_{1.67} \mathrm{O}_{4}$, respectively.

요 약 리튬 흡착제용 신규 전구체인 $\mathrm{Li}_{1.6}(\mathrm{MnM})_{1.6} \mathrm{O}_{4}(\mathrm{M}=\mathrm{Cu}, \mathrm{Ni}, \mathrm{Co}, \mathrm{Fe})$ 을 수열법에 의해 합성한 후에, 물리화학적인 성질을 고찰하였다. $\mathrm{XRD}$ 와 $\mathrm{HRTEM}$ 을 이용한 분석 결과로부터 $\mathrm{Co}$ 를 도핑한 경우에는 본래의 스피넬 구조가 유지되는 반면에, $\mathrm{Cu}, \mathrm{Ni}, \mathrm{Fe}$ 를 도핑한 경우에는 구조적인 변화가 발생하는 것을 확인하였다. $\mathrm{Co}$ 도핑에 의해 확인된 구조의 안정화 는 산처리에 의해 리튬을 침출시킨 후에도 유지되었다. 해수에 함유된 리튬을 흡착하는 효율은 Co가 도핑된 망간 산화물 인 $\mathrm{Li}_{1.6}\left[\mathrm{MnCo}_{1.6} \mathrm{O}_{4}\right.$ 가 상업적으로 적용 가능한 $\mathrm{Li}_{1.33} \mathrm{Mn}_{1.67} \mathrm{O}_{4}$ 보다 우수한 특성을 나타내었다. 해수 $1 \mathrm{~g}$ 으로부터 흡착되는 $\mathrm{Li}$ 의 양은 $\mathrm{Li}_{1.6}\left[\mathrm{MnCo}_{1.6} \mathrm{O}_{4}\right.$ 를 사용했을 경우에 $35 \mathrm{mg}$ 이었고, $\mathrm{Li}_{1.33} \mathrm{Mn}_{1.67} \mathrm{O}_{4}$ 을 사용했을 경우에는 $16 \mathrm{mg}$ 이었다.
\end{abstract}

Key Words : Li-adsorbent, Spinel-type managanese oxide. Co-dopant, Li absorption efficiency

\section{Introduction}

Lithium is a soft, silver-white metal that belongs to the alkali metal group of chemical elements. It is a very important element as raw materials in several industrial fields, e.g., ceramics, lithium batteries. lubricating greases, coolant adsorbent, pharmaceuticals etc. Recently, there is an increasing demand for further lithium production

This work was supported by Ministry of Land Transport and Maritime Affairs (2011)

${ }^{*}$ Corresponding Author : Chung, Kang-Sup(ksc@kigam.re.kr)

Received September 20, 2011

Revised October 4, 2011

Accepted October 6, 2011 
because of the widespread hopes of using rechargeable lithium batteries in electric vehicles and dispersed energy storage systems. However, the whole amount of lithium from the land is limited. Therefore, alternative resources should be found to satisfy the increasing demands. Seawater, which contains 250 billion tons of lithium in total, has thus recently been noticed as possible resources of lithium.

It is a very useful and promising method to use adsorbents that has the high selectivity for lithium ion for recovering the lithium from the seawater. Lithium manganese oxides with spinel structure have been extensively investigated as adsorption materials for lithium [1-6]. Materials such as $\gamma-\mathrm{MnO}_{2}, \mathrm{H}_{1.33} \mathrm{Mn}_{1.67} \mathrm{O}_{4}$, and $\mathrm{MnO}_{2} \cdot 0.5 \mathrm{H}_{2} \mathrm{O}$ derived from the precursors $\mathrm{LiMn}_{2} \mathrm{O}_{4}$, $\mathrm{Li}_{1.33} \mathrm{Mn}_{1.67} \mathrm{O}_{4}$ and $\mathrm{Li}_{1.6} \mathrm{Mn}_{1.6} \mathrm{O}_{4}$, respectively, are known as lithium ion selective adsorbents [7-14].

In this work, new precursors $\mathrm{Li}_{1.6}(\mathrm{MnM})_{1.6} 0_{4} \quad(\mathrm{M}=3 \mathrm{~d}$ tramsition metal) with spinel structure were prepared by hydrothermal method. Their structure and chemical properties as a precursor of lithium adsorbent were analyzed and discussed.

\section{Experimental}

Reagent grade $\mathrm{LiOH}$ and $\gamma-\mathrm{MnOOH}$ were used as starting materials to synthesize orthorhombic $\mathrm{LiMnO}_{2}$ by hydrothermal method. Then the $\mathrm{LiMnO}_{2}$ was calcined at $450^{\circ} \mathrm{C}$ for 10 hours in air with or without transition metal to get $\mathrm{Li}_{1.6}(\mathrm{MnM})_{1.6} \mathrm{O}_{4}(\mathrm{M}=3 \mathrm{~d}$ transition metal). Lithium ion-sieve, $\mathrm{H}_{1.6}(\mathrm{MnM})_{1.6} \mathrm{O}_{4}$, was obtained by leaching the $\mathrm{Li}_{1.6}(\mathrm{MnM})_{1.6} \mathrm{O}_{4}$ with dilute hydrochloric acid (below 1 moldm ${ }^{-3}$ ). The structural information of the $\mathrm{Li}_{1.6}(\mathrm{MnM})_{1.6} \mathrm{O}_{4}$ was obtained with X-ray Diffractometer (XRD, Panalytical Xpert-MPD coupled with a $\mathrm{Cu}-\mathrm{K} \alpha$ radiation tube) and high resolution transmission electron microscopy (HRTEM, JEOL, JEM-2100F). The extraction of lithium ion from the $\mathrm{Li}_{1.6}(\mathrm{MnM})_{1.6} \mathrm{O}_{4}$ was achieved by acid-treatment to get the information on acid intensity of lithium ion. The $\mathrm{Li}_{1.6}(\mathrm{MnM})_{1.6} \mathrm{O}_{4}$ powder was dissolved in a mixture of $\mathrm{H}_{2} \mathrm{SO}_{4}$ and $\mathrm{H}_{2} \mathrm{O}_{2}$. And then each content of lithium, transition metal and manganese in the $\mathrm{Li}_{1.6}(\mathrm{MnM})_{1.6} \mathrm{O}_{4}$ was determined by AAS(atomic absorption spectrometry) and inductively coupled plasma coupled mass spectrometer (ICP-AES) from the solution. The available oxygen of each sample was determined by the standard oxalic acid method [15]. The mean oxidation number $\left(\mathrm{Z}_{\mathrm{Mn}}\right)$ of manganese was evaluated as described in the literature [6].

\section{Results and Discussion}

In order to know the structure of the synthesized $\mathrm{Li}_{1.6} \mathrm{Mn}_{1.6} \mathrm{O}_{4}$ and its structural stability of after leaching, $\mathrm{X}$-ray diffractions have been performed, as shown in Fig. 1. The indexing results indicate that the $\mathrm{Li}_{1.6} \mathrm{Mn}_{1.6} \mathrm{O}_{4}$ (Fig. 1(b) obtained by calcination of $\mathrm{LiMnO}_{2}$ (Fig. 1(a) has a spinel structure. The intensity and sharpness of the spinel peaks greatly decreased, as shown in Fig. 3(c), after lithium was leached out from the $\mathrm{Li}_{1.6} \mathrm{Mn}_{1.6} \mathrm{O}_{4}$ by acid treatment. This means that the structural stability is not good, and the $\mathrm{H}_{1.6} \mathrm{Mn}_{1.6} \mathrm{O}_{4}$ given by acid treatment is not effective as a lithium adsorbent. In other words, the quality of the synthesized $\mathrm{Li}_{1.6} \mathrm{Mn}_{1.6} \mathrm{O}_{4}$ as a precursor is not good. To improve the precursor performance, Mn was substituted by other $3 \mathrm{~d}$ transition metals such as $\mathrm{Cu}, \mathrm{Ni}$, Fe, Co.

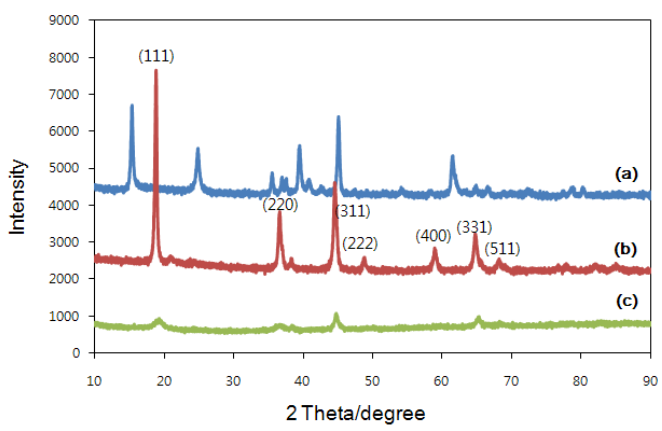

[Fig. 1] XRD patterns of the (a) $\mathrm{LiMnO}_{2}$, (b) $\mathrm{Li}_{1.6} \mathrm{Mn}_{1.6} \mathrm{O}_{4}$ and (c) acid-treated $\mathrm{Li}_{1.6} \mathrm{Mn}_{1.6} \mathrm{O}_{4}$.

Figure 2 shows the XRD patterns of the $3 \mathrm{~d}$ transition metal-doped $\mathrm{Li}_{1.6} \mathrm{Mn}_{1.6} \mathrm{O}_{4}$. The spinel structure of the $\mathrm{Li}_{1.6} \mathrm{Mn}_{1.6} \mathrm{O}_{4}$ was not changed by Cobalt doping (Fig 2(c), whereas new XRD peaks originating from structural changes were observed in the case of $\mathrm{Cu}$ or $\mathrm{Ni}$ or $\mathrm{Fe}$ doping (Fig. 2(a), (b), (d)). The Cobalt ions are located in $16 \mathrm{~d}$ octahedron site of $\mathrm{Mn}$, which is in fair agreement with that of the cubic structure (space group $F d \overline{3} \mathrm{~m}$ ). 
This results clearly reveals that Cobalt is very effective as a doping element because the spinel is a favorable structure to precursor as a lithium adsorbent.

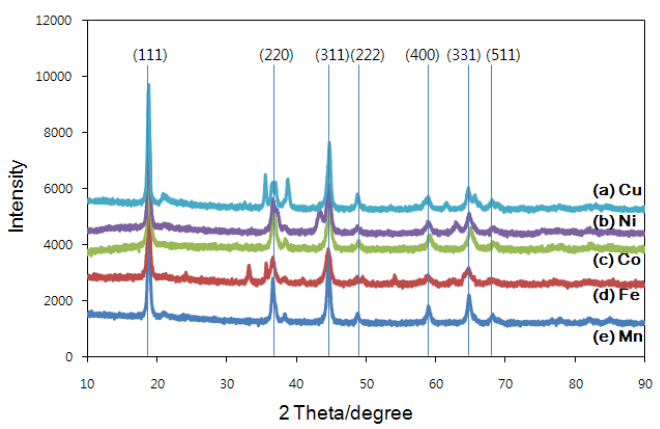

[Fig. 2] XRD patterns of 3d transition metal-doped $\mathrm{Li}_{1.6} \mathrm{Mn}_{1.6} \mathrm{O}_{4}$.

On the basis of the XRD results shown in Fig. 2, Cobalt is selected as a dopant toward $\mathrm{Li}_{1.6} \mathrm{Mn}_{1.6} \mathrm{O}_{4}$. The content of Cobalt was between 5 and $25 \%$. In the content range, no structural changes in the Cobalt-doped $\mathrm{Li}_{1.6} \mathrm{Mn}_{1.6} \mathrm{O}_{4}$ powders were observed from its XRD (not shown here). Lithium was leached out from the Cobalt-doped $\mathrm{Li}_{1.6} \mathrm{Mn}_{1.6} \mathrm{O}_{4}$ powders by acid treatment, and then XRD analysis was performed to know their chemical property as a precursor of $\mathrm{Li}$ adsorbent. Their XRD patterns are shown in Fig. 3. All the peaks were in fair agreement with those of cubic structure of $F d \overline{3} \mathrm{~m}$. Also they could be marked with $F d \overline{3} m$ of spinel structure. Thus it is considered that the Cobalt-doped $\mathrm{Li}_{1.6} \mathrm{Mn}_{1.6} \mathrm{O}_{4}$ powders after acid treatment have a well arranged spinel structure. These XRD results indicate that $\mathrm{Li}$ maintains the spinel structure, when it goes into the Mn site.

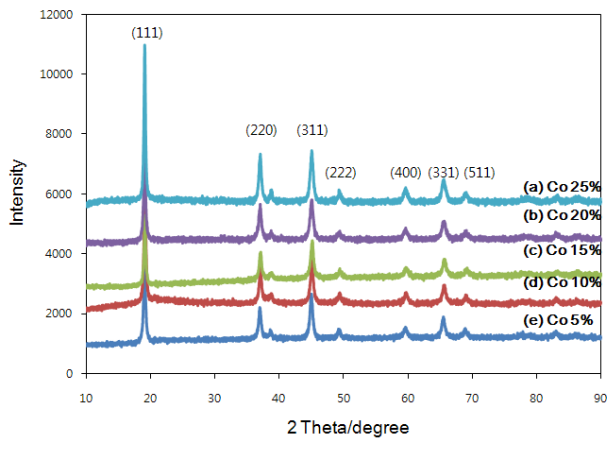

[Fig. 3] XRD patterns of Cobalt-doped $\mathrm{Li}_{1.6} \mathrm{Mn}_{1.6} \mathrm{O}_{4}$ after acid treatment.
Additional information on the structure of the Cobalt-doped $\mathrm{Li}_{1.6} \mathrm{Mn}_{1.6} \mathrm{O}_{4}$ was confirmed with HRTEM. Figure 4 shows a electron diffraction pattern taken from the sample of $\mathrm{Li}_{1.6}[\mathrm{MnCo}]_{1.6} \mathrm{O}_{4}$. As the result of phase identification of Fig.4, this pattern was identified as $\mathrm{B}=[011]$ of the single crystalline having spinel structure $(\mathrm{a}=8.2 \AA)$.

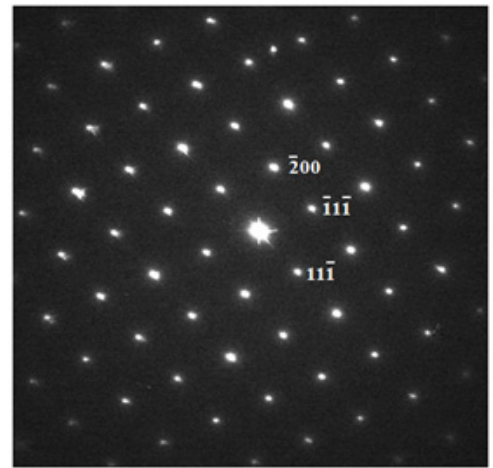

Spinel structure, $B=[011], a=8.2$

[Fig. 4] An HRTEM image of the $\mathrm{Li}_{1.6}[\mathrm{MnCo}]_{1.6} \mathrm{O}_{4}$.

Chemical analysis was carried out with an AAS and ICP-AES system to know the performance as a adsorbent according to the amount of Cobalt doping. Metal ion eruption in the samples proceeded in 0.5 moldm $^{-3} \mathrm{HCl}$ aqueous solution for 3 days. The AAS and

ICP-AES results are shown in Table 1 . It is known that appropriate oxidation number of $\mathrm{Mn}$ is +4 for high qualified lithium adsorbent. Therefore, the AAS and ICP-AES results, those are close to +4 , indicate that the $\mathrm{Li}_{1.6}[\mathrm{MnCo}]_{1.6} \mathrm{O}_{4}$ is a good precursor. Consequently Coblat could be ionized best of all in $3 \mathrm{~d}$ transition metal used in this work. Lithium ion extracted from $\mathrm{Li}_{1.6}[\mathrm{MnCo}]_{1.6} \mathrm{O}_{4}$ spinel was produced by ion exchange method. This result shows that lithium ion was extracted selectively from this materials.

[Table 1] Chemical composition for the original and acid-treated sample

\begin{tabular}{|l|l|c|}
\hline \multicolumn{1}{|c|}{ Sample } & \multicolumn{1}{|c|}{$\begin{array}{c}\text { Chemical } \\
\text { Formula }\end{array}$} & $\begin{array}{c}\text { Average } \\
\text { Oxidation state } \\
\text { of } \mathrm{Mn}\end{array}$ \\
\hline $\mathrm{Li}^{+}$type & & \\
\hline $\mathrm{Li}_{1.6}[\mathrm{MnCo}]_{1.6} \mathrm{O}_{4}$ & $\mathrm{Li}_{2.1} \mathrm{Mn}_{1.37} \mathrm{Co}_{0.15} \mathrm{O}_{4}$ & 3.87 \\
\hline $\mathrm{H}^{+}$type & & \\
\hline $\mathrm{H}_{1.6}[\mathrm{MnCo}]_{1.6} \mathrm{O}_{4}$ & $\mathrm{Li}_{0.08} \mathrm{Mn}_{1.32} \mathrm{Co}_{0.18} \mathrm{O}_{4}$ & 3.75 \\
\hline
\end{tabular}


Figure 5 shows the extractibility of the $\mathrm{Li}_{1.6}[\mathrm{MnCo}]_{1.6} \mathrm{O}_{4}$ spinels. To extract the lithium ion and $3 \mathrm{~d}$ transition metal from the spinels, the samples were soaked in the $\mathrm{HCl}$ aqueous solution for 3 days. The amount of extracted manganese ion was quite small compared to that of lithium ion. The ability of extraction of lithium ion has a increasing tendency with the decrease the amount of Cobalt-doping. The amount of $\mathrm{Li}$ adsorbed was estimated to be $35 \mathrm{mg}$ per $1 \mathrm{~g}$-adsorbent from Fig. 5. This value is much larger than that obtained by commercially available $\mathrm{Li}_{1.33} \mathrm{Mn}_{1.67} \mathrm{O}_{4}$, in which relatively small amount of Li (16 mg per 1g-adsorbent) was adsorbed.

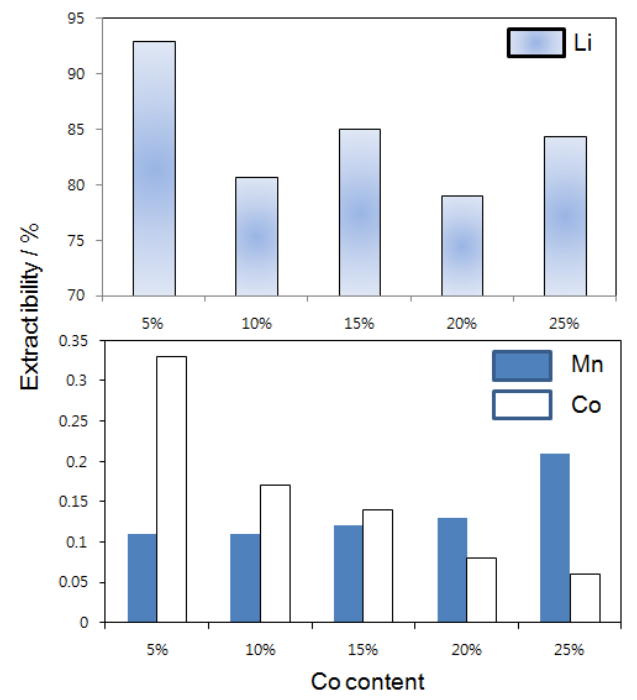

[Fig. 5] Extractibility of the acid-treated Cobalt-doped $\mathrm{Li}_{1.6} \mathrm{Mn}_{1.6} \mathrm{O}_{4}$

\section{Conclusions}

In this work, a spinel-type manganese oxide, $\mathrm{Li}_{1.6}[\mathrm{MnCo}]_{1.6} \mathrm{O}_{4}$, was synthesized by hydrothermal method with good reproducibility. The $\mathrm{Li}_{1.6}[\mathrm{MnCo}]_{1.6} \mathrm{O}_{4}$ showed extraordinarily excellent property as a new precursor of $\mathrm{Li}$ adsorbent.

Acknowledgements : This research was supported by a grant (PGB047) from the Development of Technology for Extraction of Resources Dissolved in Sea Water Program funded by Ministry of Land Transport and Maritime Affairs (2011).

\section{References}

[1] J. C. Hunter., "Preparation of a new crystal form of manganese dioxide: $\mathrm{\lambda}-\mathrm{MnO}_{2}$ " Journal of Solid State Chemistry, 39, pp. 142-147, September, 1981.

[2] K. Ooi, Y. Miyai. and S. Katoh., "Preparation and ion-exchange properties of ion-sieve manganese oxide based on $\mathrm{Mg}_{2} \mathrm{MnO}_{4}$ " Solvent Extr. Ion Exch., 5, pp. 561-572, 1987.

[3] Q. Feng, Y. Miyai, H. Kanoh. and K. Ooi., " $\mathrm{Li}^{+}$ Exracntion/Insertion with Spinel-Type Lithium Manganese Oxides, Characterization of Redox-Type and Ion-Exchange -Type Sites" Langmuir., 8, pp. 1861-1867, 1992.

[4] Q. Feng, H. Kanoh. and K. Ooi., "Manganese oxide porous crystals" J. Mater. Chem., 9, pp. 319-333, 1999.

[5] R. Chitrakar, H. Kanoh, Y. Miyai. and K. Ooi., "A New Type of Manganese Oxide $\left(\mathrm{MnO}_{2} \cdot 0.5 \mathrm{H}_{2} \mathrm{O}\right)$ Derived from $\mathrm{Li}_{1.6} \mathrm{Mn}_{1.6} \mathrm{O}_{4}$ and Its Lithium Ion-Sieve Properties" Chem. Mater., 12, pp. 3151-3157, September, 2000.

[6] Qi Feng, Yoshitaka Miyai, Hirofumi Kanoh, Kenta Ooi., "Lithium(1+) and magnesium(2+) extraction and lithium(1+) insertion reactions with lithium magnesium manganese oxide $\left(\mathrm{LiMg}_{0.5} \mathrm{Mn}_{1.5} \mathrm{O}_{4}\right)$ spinel in the aqueous phase", Chem. Mater., 5 (3), pp 311-316, 1993.

[7] Y. -S. Kim, H. Kanoh, T. Hirotsu and K. OOi, "Determination of the Chemical Bonding of Ionic Lithium and Proton Exchange in Spinel-Type Manganese Oxides", Bull. Chem. Soc. Jpn., 75, pp. 55-58, April, 2002.

[8] Y. -S. Kim, H. Kanoh, T. Hirotsu and K. OOi., "Chemical bonding of ion-exchange type sites in spinel-type manganese oxides $\mathrm{Li}_{1.33} \mathrm{Mn}_{1.67} \mathrm{O}_{4}$ ", Mater. Res. Bull., 37, pp. 391-396, September, 2002.

[9] Y. -S. Kim, H. Kanoh, Ramesh Chitrakar, T. Hirotsu and K. OOi., "Electronic Structure and Chemical Bonding of $\mathrm{Li}$ and Protons in Spinel Type Manganese Oxides by Cluster Calculation", Chem Lett., pp. 1224-1225, July, 2000.

[10] B. Ammundsen, G. R. Burns, M. S. Islam, H. Kanoh. and J. Roziere., "Lattice Dynamics and Vibrational Spectra of Lithium Manganese Oxides" A Computer Simulation and Spectroscopic Study"J. Phys. Chem. B., 103, pp. 5175-5180, JUNE, 1999.

[11] B. Ammundsen, J. Roziere. and M. S. Islam., "Atomistic Simulation Studies of Lithium and Proton Insertion in Spinel Lithium Manganates" J. Phys. Chem. B., 101, pp. 8156-8163. October, 1997.

[12] B. Ammundsen, D. J. Jones, J. Roziere. and G. R. 
Burns., "Mechnism of Proton Insertion and Characterization of the Proton Sites in Lithium Manganate Spinels" Chem. Mater., 7, pp. 2151-2160, 1995.

[13] B. Ammundsen, D. J. Jones, J. Roziere. and G. R. Burns., "Effect of Chemical Extraction of Lithium on the Local Structure of Spinel Lithium Manganese Oxides Determined by X-ray Absorption Spectroscopy", Chem. Mater., 8, pp. 2799-2808, 1996.

[14] B. Ammundsen, D. J. Jones. and J. Roziere., "Ion Exchange in Manganese Dioxide Spinel: Proton, Deuteron, and Lithium Sites Determined from Neutron Powder Diffraction Data", Chem. Mater., 10, pp. 1680-1687, MAY, 1998.

[15] Japan Industrial Standard (JIS), M8233, 1969

\section{Yang-Soo Kim}

[Regular member]

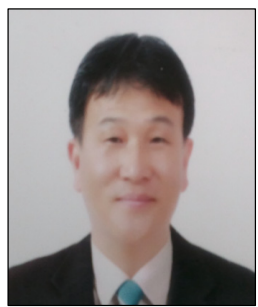

- Feb. 1991: Chonbuk Univ., Metallurgical Eng., MS

- Mar. 1999: Kyoto Univ., Mater. Sci. End., $\mathrm{PhD}$

- June. $2006 \sim$ Current : Korea Basic Science Institute, Principal Researcher

$<$ Research Interests $>$

New Li energy materials design using DFT

Won-Jin Moon

[Regular member]

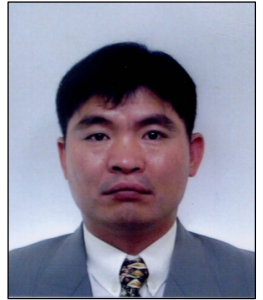

- Feb. 1995: DongA Univ., Metallurgical Eng., MS

- Mar. 2000: Nagoya Univ., Quantum Mechanics, PhD

- Apr. $2000 \sim$ Dec. 2001 : IBM/ITES, Japan, Researcher

- Mar. $2005 \sim$ Current : Korea Basic Science Institute, Principal Researcher

$<$ Research Interests $>$

FE-TEM, Energy materials
Soon-Ki Jeong

[Regular member]

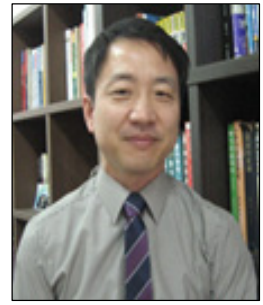

- Aug. 1996 : Hanyang Univ. Dept. of Industrial Chemistry, MS

- Mar. 2002 : Kyoto Univ. Dept. of Energy \& Hydrocarbon Chemistry, $\mathrm{PhD}$

- Feb. $2005 \sim$ current : Soonchunhyang Univ., Dept. of Chemical Engineering, Associate Professor

$<$ Research Interests $>$

Primary \& Secondary Batteries, In-situ SPM

Dae-Hee Won

[Regular member]

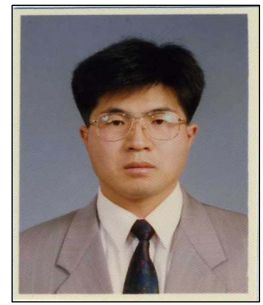

- Feb, 1996 : Chonbuk National Univ., M.S.

- Feb. 1999 : Chonbuk National Univ., Ph.D.

- July. 2007 Oct. 210 Hub Univ. for industrial collaboration, Professor

$<$ Research Interests $>$

Energy materials, information, biomaterials

Sang-Ro Lee

[Regular member]

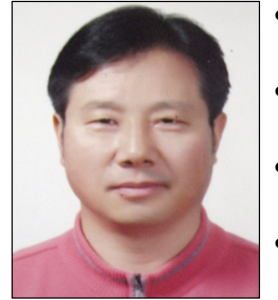

- Feb. 1994 : Korea Univ., Metallurgical Eng., MS

- Feb. $1994 \sim$ Aug. 2003 : POSCO Tech.Lab. Researcher

- Sep. 2003 July. 2010 : A1 Engineering. Engineer

- Aug. 2010 current : KFNET. Co. LTD. Researcher

$<$ Research Interests $>$

Ore dressing, Solvent Extraction, Rechargeable Battery 


\section{Byoung-Gyu Kim [Regular member]}

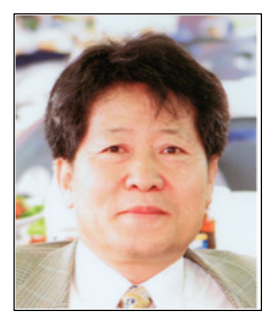

- Feb. 1985 : Chonbuk Univ., Industrial Chemistry, MS

- Mar. 1993 : Tohoku Univ., Applied Chemistry, PhD

- Oct. $1993 \sim$ current : Korea Institute of Geoscience and Mineral Resources, Mineral Resources Research Division, Principal Researcher

$<$ Research Interests $>$

Seawater-Dissolved Resources Recovery, Metal Adsorbent Synthesis

\section{Kang-Sup Chung}

[Regular member]

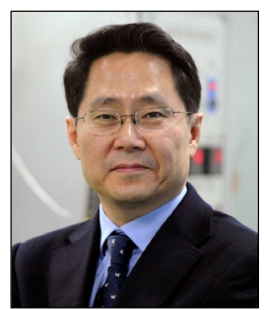

- Feb. 1991 : Seongkyunkwan Univ., Inorganic Chemistry, MS

- Feb. 1995 : Seongkyunkwan Univ., Inorganic Chemistry, PhD

- Sep. $1986 \sim$ current : Korea Institute of Geoscience and Mineral Resources, Mineral Resources Research Division, Principal Researcher

$<$ Research Interests $>$

Seawater-Dissolved Resources Recovery,

Inorganic Syntheses and Evaluation 